\title{
DAMAGES FOR BREACH OF AN EXPRESS DRILLING COVENANT
}

\author{
MAURICE J. SYCHUK*
}

\begin{abstract}
Although legal problems of oil and gas production are governed by general principles of the law of property, contracts, torts, etc., there are certain situations in the oil and gas industry where these rules do not quite fit, and if they do fit, their application is so strained that the rule becomes a special rule, and becomes a part of that separate body of law referred to as oil and gas law. Damages for breach of an express drilling covenant is such an area. This article distinguishes a covenant to drill a well from a covenant to protect against drainage and from a covenant of reasonable development, discusses the four rules that have been used by the courts in assessing damages for breach of a covenant to drill a well, analyzes the Canadian decisions on breach of a covenant to drill a well and concludes that, in a situation where the plaintiff and the defendant both have an interest in the property on which the well is to be drilled, the Canadian courts will grant damages for breach of a covenant to drill a well on the basis of the loss of royalty rule and on the basis of the loss of market value rule.
\end{abstract}

\section{A. INTRODUCTION}

Although the title of the topic assigned to me is "Remedies for Breach of Covenants and Conditions of Joint Venture Agreements", I have restricted this paper to a discussion of the principles to be applied in determining the amount of damages caused by a breach of covenant to drill an oil and gas well. My reason for doing so is as follows; remedies for breach of covenants and conditions in joint venture agreements are governed by the general principles of the law of contracts, such as, damages, specific performance, rescision, injunction and forfeiture. There is no disagreement as to the general principles to be applied, but in their application to the facts of a particular situation, considerable difference of opinion may arise, and as such, I felt that it would be more advantageous to discuss a particular area in detail, and thereby illustrate the application of general principles to a specific problem, rather than discussing remedies in general.

Notwithstanding the fact that legal problems of oil and gas production are governed by general principles of the law of property, contracts, torts, etc., there are certain situations in the oil and gas industry where these rules do not quite fit, and if they do fit, their application is so strained, that the rule becomes a special rule, and becomes a part of that separate body of law referred to as oil and gas law. It is submitted that damages for failure to drill a well is such an area, and as such, warrants an indepth analysis of the application of the general principles of the law of damages for breach of contract.

\section{B. DAMAGES FOR BREACH OF CONTRACT}

The object of the law in awarding damages for breach of contract is to put the plaintiff, in so far as money can do it, in the same position as he would have been had the contract been performed. ${ }^{1}$ The rule

- B.A. LL.B. (Sask.), M.C.L. (Southern Methodist University), member of the Law Societies of Alberta and Saskatchewan. Associate Professor, Faculty of Law, The University of Saskatchewan.

1 See generally, Mayne and McGregor On Damages 108-130 (12th ed.). 
governing damages for breach of contract was laid down in the case of Hadley v. Baxendale, ${ }^{2}$ and the modern restatement of the rule was declared by Asquith L.J. in Victoria Laundry v. Newman ${ }^{3}$ as follows:

In cases of breach of contract the aggrieved party is only entitled to recover such part of the loss actually resulting as was at the time of the contract reasonably foreseeable as liable to result from the breach.

What was at that time reasonably so foreseeable depends on the knowledge then possessed by the parties or, at all events, by the party who later commits the breach.

For this purpose, knowledge 'possessed' is of two kinds; one imputed, the other actual. Everyone, as a reasonable person, is taken to know the 'ordinary course of things' and consequently what loss is liable to result from a breach of contract in that ordinary course. This is the subject matter of the 'first rule' in Hadley v. Baxendale. But to this knowledge, which a contract-breaker is assumed to possess whether he actually possesses it or not, there may have to be added in a particular case knowledge which he actually possesses, of special circumstances outside the 'ordinary course of things,' of such a kind that a breach in those special circumstances would be liable to cause more loss. Such a case attracts the operation of the 'second rule' so as to make additional loss also recoverable. ${ }^{4}$

In other words, the defendant is liable for all damages that occur in the ordinary course of things, whether he knows the ordinary course of things or not, but he is only liable for damages that are greater than damages that occur in the ordinary course of things, if he has actual knowledge of special circumstances outside the ordinary course of things which increase the damages upon breach of contract. It is very difficult to determine which rule is applicable in a particular case, i.e., if a defendant knew a particular fact, he will be liable on the basis of the second rule, on the other hand, knowledge of the same fact might have been imputed to him even if he had not known it, so that he would have been liable under the first rule. In determining liability for breach of contract, actual knowledge is only relevant if without that knowledge there would not have been any liability. ${ }^{5}$

\section{TYPES OF DRILLING CLAUSES}

In discussing damages for breach of a covenant to drill a well, it is important to note that before the question of damages arises there must be a firm drilling commitment on the part of the defendant." A drilling clause in a lease, assignment or farmout agreement can be drafted in one of the following four ways, namely: ${ }^{7}$

(a) As a clause creating a special limitation on the estate conveyed. If the drilling clause creates a special limitation on the estate conveyed, the defendant is not bound to drill, and if he does not drill by the specified time, his interest terminates automatically, and the plaintiff has no right to damages. An example of a clause creating a special limitation on the estate conveyed is the typical "unless" delay rental clause."

2 (1854) 9 Ex. 341.

3 [1949] 2 K.B. 528. See also The Heron II: Koufos v. Czarnikow, Ltd. [1967] 3 All E.R. 686; Leitch Gold Mines Ltd. v. Texas Gulf Sulphur Co. (1969) 3 D.L.R. 161; Toronto Type Foundry Ltd. v. Miehle-Goss-Dexter Inc. (1969) 5 D.L.R. 578.

+ Id. at 539-540.

5 Mayne and McGregor, supra, n. 1 at 119.

i Godfrey, The Measure of Damages for Breach of an Express Covenant to Drill a Test Well, (1954) 8 Wyoming Law Journal 142 at 143.

i 5 Williams and Meyers, Oil and Gas Law Para. 884.1, p. 558.

* For a discussion of the automatic termination of an "unless" delay rental clause, see East Crest Oil v. Strohschein (1952) 4 W.W.R. (N.S.) 553. 
(b) As a clause creating a condition subsequent. ${ }^{\circ}$ If the estate granted or assigned is conditional on the drilling of a well by the defendant, failure to drill gives the grantor or assignor the power to determine the existing interest, but he may not sue for damages, because the defendant has not unconditionally promised to drill a well." If the drilling of the well is a condition precedent, the interest never vests, and again, there being no unqualified promise, the grantor or assignor has no right of action for damages for failure to drill a well.

(c) As a clause creating a covenant. If the drilling clause contains an unconditional promise to drill, failure to drill constitutes a breach of contract entitling the grantor or assignor to damages for breach of an express covenant to drill a well.11 In addition, where damages are inadequate, the plaintiff may be entitled in equity to cancellation of the lease, assignment or farmout.":

(d) As a clause creating both a covenant and a condition subsequent. $^{13}$ If the drilling clause creates both a covenant and a condition subsequent, the plaintiff can sue to recover damages for breach of covenant to drill a well, or he can sue for an order terminating the interest for breach of a condition subsequent. Although a drilling clause containing both a covenant and a condition subsequent usually provides for alternative, rather than cumulative remedies, ${ }^{14}$ there is authority for the proposition that such a promisee may both terminate the contract and recover damages for its breach.": In Prudential Trust Company

o The distinction between a clause creating a special limitation and one creating a condition subsequent, is that relief from forefeiture (see s. 32(o), Judicature Act, is see Oil City Petroleums (Leduc) Limited v. American Leduc Petroleums Limited (1951) 2 W.W.R. (N.S.) 371 .

10 An example of such a clause is as follows: "The forfeiture provided for in the within paragraph shall be the exclusive remedy of lessor against lessee in the event of failure of lessee to comply with any of the provisions of the within lease designated and relating to drilling requirements hereof." 4 Williams and Meyers, Oil and Gas Law Para. 681, p. 320 .

11 For an example of a clause containing an unconditional promise to drill, see the offset well clause in Albrecht v. Imperial Oil Limited (1957) 21 W.W.R. (N.S.) 560 at 561-562.

125 Williams and Meyers, Oil and Gas Law Para. 884, pp. 572-573.

13 An example of such a clause is as follows:

"23. Should Farmee make any default in any term, covenant or condition of this Agreement or any Lease and permit such default to continue for Thirty (30) days after notice thereof in writing has been given to it by the Company, then the Company may by notice in writing to Farmee cancel and determine the conveyance and the entire interest of Farmee under this Agreement and it shall be lawful for the Company, into and upon the lands (or any part thereof in the name of the whole) to re-enter, and the same to have again, repossess and enjoy. Any cancellation and determination aforesaid shall not apply to any spacing unit on which there is located a well capable of producing the petroleum substances in paying quantities, or on which a well is being drilled at the time of cancellation and determination, unless the default aforesaid is in respect of such spacing unit or some portion thereof, either alone or together with any other portion or portions of the lands. The rights either alone or together with any other portion or portions of the lands. The rights
herein granted to the Company shall be in addition to and not in substitution for any other right or remedy which the Company may have under this Agreement and specifically the exercise of such rights shall not serve to deprive the Company either wholly or partially of any other right or remedy including damages and indemnity." 1 Lewis and Thompson, Canadian Oil and Gas Div. C, Form B. 2(a).

14 An example of such a clause is as follows:

"Lessee covenants and agrees, for himself, his heirs and assigns, that within ninety (90) days from the date hereof, lessee shall commence operations for the drilling of a well in search of oil and gas on sald above described land and shall diligently prosecute such drilling operations until the depth of prosecute such drilling operations untll the depth of
reached. In the event that the lessee or his assign fails to drill the well herein reached. In the event that the lessee or his assign fails to drill the well herein
provided for, the lessor, his heirs and assigns may, at their option, recover their damages therefor or may re-enter and terminate this lease. In the event that lessor, his heirs or assigns, shall elect to terminate this lease for breach of this drilling covenant, lessor shall give ten (10) days notice before instituting action during which lessee may repair the breach by commencement of drilling operations." Williams and Meyers, supra, n. 12 at 571-572.

15 Williams and Meyers, supra n. 12 at 576-578. See also Huie, Walker, and Woodward, Cases and Materials on Oil and Gas 519 (1960). 
Limited v. Wagner Oils Limited," Chief Justice McLaurin held that the presence of a forfeiture clause did not prevent the defendant from being liable for damages for breach of an express drilling obligation, although it is not clear from the decision whether or not the plaintiff had exercised his right to re-enter the premises. ${ }^{17}$

\section{DAMAGES FOR BREACH OF A COVENANT TO PROTECT AGAINST DRAINAGE}

In a discussion of damages for breach of a covenant to drill a well, care should be taken to distinguish a covenant to drill a well from a covenant, whether express or implied," to protect against drainage. " Oil and gas are fugacious substances and the covenant to protect the leashold from drainage serves to protect the lessor from loss of oil or gas due to the migration of the oil and gas to the adjoining land. The covenant, whether express or implied, requires the lessee to drill a well to protect against drainage if a prudent operator would do so in the same circumstances.

In order to establish a breach of the covenant to protect against drainage, a lessor must establish firstly that substantial drainage has taken place and, secondly, that the offset well would produce oil or gas in paying quantities, that is, produce in sufficient quantities to repay the cost of drilling, equipping and operating the well, plus a reasonable profit on the investment of the lessee in the said well. The burden of establishing breach of the protection covenant is on the lessor. ${ }^{20}$

Although the protection covenant requires the drilling of an offset well or wells, and has often been referred to as the "offset well covenant", a covenant to protect against drainage must be distinguished from the offset well clause found in a typical Canadian oil and gas lease, as follows:

In the event of commercial production being obtained from any well drilled on any spacing unit laterally adjoining the said lands and not owned by the Lessor, or, if owned by the Lessor, not under lease to the Lessee, then unless a well has been or is being drilled on the spacing unit of the said lands laterally adjoining the said spacing unit on which production is being so obtained and to the horizon in the formation from which production is being so obtained, the Lessee shall, within six (6) months from the date of said well being placed on regular production, either:

(a) Commence or cause to be commenced within the six (6) month period aforesaid operations for the drilling of an offset well on the spacing unit of the said lands laterally adjoining the said spacing unit on which

11 (1954) 11 W.W.R. (N.S.) 371. See also Cotter v. General Petroleums Ltd. (1950) 4 D.L.R. 609, wherein the agreement provided as follows:

'3. The Optionees covenant to exercise the option within the said period, in the manner aforesaid, and in the event of their neglect or failure so to do, the Optionor shall, despite the lapse of the said option, be entitled to exercise any remedies which may be legally available to him for the breach by the Optionees of this covenant, which the parties hereto agree is given and entered into by the Optionees as the which the parties hereto agree is given and entered into by

if Id. at 373. Although subjection to both remedies seems quite harsh to the defendant, it should be remembered that in most cases the reason that the defendant has not drilled is that he belleves the property to be unproductive of oil and gas. As such. the alternative of forfeiture is not very valuable to the plaintiff, and if the defendant is not subject to the payment of damages for breach of an express covenant to drill a well. he will for all practical purposes avoid llability for his breach of covenant since he will not suffer any hardship by having an interest, which he in all likelihood is prepared to surrender, determined by a court order. Alternatively, if a defendant liable to pay damages wishes to retain his interest in the property, he may be relieved from forfeiture by the court.

1s For an example of an express covenant to use reasonable diligence to protect against drainage, see Farmers Mutual Petroleums v. United States Smelting (1962) 39 W.W.R. (N.S.) 682 at $684-685$.

1!) See generally, 5 Williams and Meyers, Oil and Gas Law Para. 821-826, pp. 78-207.

so Id. at $\mathbf{7 9 - 8 0}$. 
production is being so obtained, and thereafter drill the same to the horizon in the formation from which production is being obtained from the said adjoining spacing unit; or

(b) Surrender all or any portion of the said lands pursuant to the provisions of paragraph 14 hereof, provided that the lands surrendered shall include that portion of the said lands comprised in the said spacing unit laterally adjoining the said spacing unit on which production is being so obtained; or

(c) Where production is being obtained from the said lands from a formation other than the formation from which commercial production is being obtained on the spacing unit laterally adjoining the said lands, surrender all formations which lie within the said lands except that formation within the said lands from which the Lessee is obtaining production.

PROVIDED, that if such well drilled on lands laterally adjoining the said lands is productive primarily or only of natural gas, the Lessee shall not be obligated either to drill an offset well or to surrender said spacing unit unless and until an adequate and commercially profitable market for natural gas which might be produced from the offset well can be previously arranged and provided.

A typical Canadian offset well clause, although inserted in the lease to prevent the implication by the courts of an implied covenant to protect against drainage, ${ }^{21}$ is not a protection covenant, but is a drilling covenant which imposes an absolute obligation on a lessee, ${ }^{22}$ under certain circumstances $^{2: 3}$ and subject to certain other alternatives, ${ }^{24}$ to commence the drilling of an offset well on the laterally adjoining spacing unit and to drill the same to the horizon from which the "robber" well is producing. In most Canadian offset well clauses, the lessor does not have to prove any drainage ${ }^{25}$ and, although the test of the prudent operator of production in paying quantities outlined above and the test of commercial production contained in Canadian oil and gas leases are similar, ${ }^{26}$ they apply to different wells.

The prudent operator test requires proof that the protection (offset) well will produce in paying quantities, whereas the test of commercial production required to trigger a Canadian offset well clause is applied to the "robber" well. Needless to say, the onus of proof on the lessor is greater under the covenant to protect against drainage than it is under the offset well clause; furthermore, although the same is not as important now with modern offset well clauses containing a right of surrender, it is possible in theory that there could be a known impermeable barrier between the spacing unit containing the robber well and the spacing unit on which the offset well is to be drilled. Under such circumstances, the offset well clause would be triggered,"i whereas the prudent operator test would not be satisfied.

United States' courts have granted the following remedies for breach of a covenant to protect against drainage: (1) cancellation of the lease,

21 Lewis, The Canadian Petroleum and Natural Gas Lease (1952) 30 Can. Bar Rev. 965 at 978 .

$2:$ See Farmers Mutual Petroleums v. United States Smelting (1962) 39 W.W.R. 682 at 685 .

23 Commercial producticn in a laterally adjoining spacing unit not owned by the lessor, see comment by Ballem (1957) 35 Can. Bar Rev. 971 at 973.

-1 Right of surrender; for an example of an of fset well clause without a right of surrender, see Albrecht v. Imperial Oil Limited (1957) 21 W.W.R. 560 .

$\therefore$ An execption is an of fset well clause whlch provides as follows:

"In the event of commercial production being obtained from any well drilled on any drilling unit laterally adjoining the said lands and not owned by the Lessor, or, if owned by the Lessor, not under lease to the Lessee, and such well is draining the said lands,. . (Emphasis added.)

26: "Commercial production shall mean the output from a well of such quantity of the leased substances or any of them as, considering the cost of drilling and production operations and price and quality of the leased substances, after a production test of Thirty (30) days, would commercially and economically warrant the drilling of a like well in the vicinity thercof."

$2-$ That is an offet well clause without a requirement that the lessor establish drainage. 
(2) conditional cancellation of the lease whereby the lease is cancelled upon the lessee's failure to drill the offset well within a specified period of time and, (3) damages. ${ }^{28}$ In the only Canadian case on point, Farmers Mutual Petroleums v. United States Smelting," "Chief Justice Bence refused rescission and granted damages, stating: ${ }^{\circ 0}$

I have found that the defendants should have drilled on four other parcels by that time to comply with the provisions of paragraph 7 respecting drainage. Failure to drill on these specific parcels is one for which the plaintiff can be compensated for in damages but they have no right to rescission of the contract for such failure. The failure did not, in my opinion, go to the root of the contract and damages are an adequate remedy.

Williams and Meyers discuss two rules that have been applied in calculating damages for breach of a covenant to protect against drainage. Firstly, the value of the lessor's royalty on oil and gas that have been lost through drainage is discussed. A criticism of this formula is that it requires the lessee to protect against all drainage, instead of protecting only against such drainage as would have been protected by a prudent operator. Secondly, the value of the lessor's royalty on the oil and gas the offset well would have produced from the time that it should have been drilled is discussed. In this regard, it should be pointed out that if the lessor receives the value of the royalty upon the oil or gas that should have been produced, and the oil remains under his land and is later produced by the lessee, the lessor will receive double royalties on the same oil and gas. ${ }^{31}$

Williams and Meyers conclude that damages calculated on the amount of oil and gas lost by drainage are adequate for past drainage, but do not take into account future drainage, and as such, they suggest that the court should grant damages for such past drainage as would have been protected by a prudent operator, and, in order to avoid the objections discussed above, grant an order for conditional cancellation of the lease. ${ }^{32}$

In Albrecht v. Imperial Oil Limited, ${ }^{33} \mathrm{Mr}$. Justice Riley, in a case dealing with a breach of an express obligation to drill an offset well, stated that the measure of damages for failure to protect against drainage is "the amount of royalty the lessor would have received had the well been drilled." ${ }_{34}$ In the Farmers Mutual Case, ${ }^{35}$ Chief Justice Bence calculated damages for breach of an express covenant to protect against drainage on the basis of the "amount drained away" formula rather than on the "amount the offset well would have produced" formula. In order to avoid the difficulties of calculating damages, some oil and gas leases

\footnotetext{
28 Williams and Meyers, supra, n. 19 at 153-156.

29 (1962) 39 W.W.R. 682 .

301 Lewis and Thompson, Canadian Oil and Gas, Div. B, Dig. 192 at 266.

31 Williams and Meyers, supra, n. 19 at 164-167. Maxwell. Damages for Breach of Express and Implied Driling Covenants, (1960) 5 Rocky Mountain Mineral Law of a covenant to protect against drainage, namely:

of a covenant to protect against drainage, namely: "Without regard to the problem of proof the measure of damages for breach of the
covenant to protect against drainage should be the value of the royalty percentage of the oil which would have been produced if the protection well had been drilled as required but which has now been lost through drainage: plus interest on these sums from the time they would have been due: plus interest on the value of the royalty percentage of the oil which would have been produced if the well had been drilled as required but which has not been drained and is still avallable for later production. Such a detailed measure probably is too sensitive for the kind of proof that can be adduced."

32 Williams and Meyers, supra, n. 19 at 176

33 (1957) 21 W.W.R. 560.

34 Id. at 564

35 (1962) 39 w.W.R. (N.S.) 682. That portion of the judgment in which Chief Justice (1962) 39 W.W.R. (N.S.) 682 . That portion of the judgment in which Chief Justice
Bence calculates damages is not reported in (1962) 39 W.W.R. (N.S.) 682 or Lewis and Thompson. Dig. 192. The calculation of damages is contained in pages 21 to 61 of the original judgment of Chief Justice Bence dated the 20th day of July, 1962.
} 
contain a Compensatory Royalty clause that provides that instead of drilling the Offset Well, the lessee may pay royalty based on the production of the "robber" well.".

\section{E. DAMAGES FOR BREACH OF A COVENANT OF REASONABLE DEVELOPMENT}

In a discussion of damages for breach of a covenant to drill a well, care should also be taken to distinguish a covenant to drill a well from a covenant, whether express or implied,": of reasonable development of the leased premises. ${ }^{1 \times}$ The covenant of reasonable development has been implied in the oil and gas lease by United States' courts to protect the lessor from delay in receiving royalties. The covenant arises when production of oil and gas from the leased premises has been obtained, and requires the operator to proceed with reasonable diligence to drill as many additional wells as are necessary, bearing in mind the interests of both the lessor and the lessee, to properly develop the premises for oil and gas. $^{30}$

In order to establish a breach of the covenant to reasonably develop, the lessor must establish that the development well will produce oil and gas in paying quantities, that is that the well will produce sufficient quantities of oil and gas to enable the lessee to recover his capital and operating expenses and enable the lessee to make a reasonable profit on his investment. ${ }^{* 0}$

As in the drainage cases, the courts have granted three types of remedies for breach of the covenant to reasonably develop, (1) cancellation, (2) conditional cancellation, and (3) damages. The measure of damages for breach of the covenant to reasonably develop has been held to be the value of the royalty that would have been paid on the oil produced if the additional development wells had been drilled when they were supposed to have been drilled."11

There have been two suggested solutions to the problem of double royalties created by the "amount that the development well would have produced" rule for measuring damages for breach of a covenant to reasonably develop. ${ }^{* 2}$ The first suggested that the interest on the value of the royalty more nearly approximates the true measure of damages. ${ }^{.3}$ This rule has been rejected because of the difficulties in fixing the period

\footnotetext{
31 An example of such a clause is as follows:

"Provided further, in lieu of drilling an offset to such gas well, Lessee shall have the option of paying Lessor a royalty equal to one-sixteenth of the net revenue derived from the gas sold from such adjacent well, and as long as Lessee may elect to pay said royalty in lieu of drilling an offset, it will be considered that gas is being produced from the premises within the meaning of the opening paragraph hereof." See comment by Bredin, (1963) 41 Can. Bar Rev. 277 at 279.

37 For an example of an express covenant to use reasonable efforts of development. see the Farmers Mutual Case (1962) 39 W.W.R. 682 at 684 .

3x See Scott. Measure of Damages for Breach of a Covenant to Drill a Test Well for Oil and Gas, (1961) 9 Kansas Law Rev. 281 at 287, as follows:

"In differentlating between the two types of covenants, courts have said that a lessee who agrees to drill with reasonable diligence does not know until judgment what drilling he should have undertaken or the cost, and, therefore, should not be required to pay the cost of drilling. The correct distinction would seem to be that a covenant to drill with reasonable diligence, that is, to drill if it would be profitable to do so, unmistakably shows a mutual understanding that the performance bargained for is the royalty and not the well itself. Under one type of covenant the lessee agrees to drill if the well would produce at a profit; under the other, he agrees to drill a well and, if it produces, to pay a royalty."

30 See generally, Williams and Meyers, Oil and Gas Law Para. 831-835, pp. 207-258.

40 Id. at $218-219$

41 Id. at 237-240.

4: See Supra, n. 31.

13 Grass v. Big Creek Development Co. (1915) 84 S.E. 750 (W.Va.).
} 
for which the interest should be computed. ${ }^{+4}$ A suggestion by the Supreme Court of Texas ${ }^{4 \pi}$ is that the lessee might be able to get equitable relief when the tract was brought to full development by permitting him to take, free of royalty obligations, that amount of oil and gas on which he had already paid royalties as part of the award of damages. ${ }^{\text {th }}$

Because in most cases, breach of a covenant to reasonably develop results in no permanent loss of oil or gas and the action is either for failure to produce the oil fast enough, or for failure to produce all of it, Williams and Meyers conclude that the courts should grant interest on the royalties that should have been received, and grant an order for conditional cancellation to avoid future problems of calculation of interest or recovery of double royalties. ${ }^{4 i}$

In the Farmers Mutual Case, Chief Justice Bence concluded that there had not been a breach of the express covenant to reasonably develop,": and as such, there is no Canadian authority on the measure of damages for breach of a covenant of reasonable development.

\section{F. RULES FOR ASSESSING DAMAGES FOR BREACH OF A COVENANT TO DRILL A WELL}

There is no controversy that the object of damages for breach of a covenant to drill a well is to place the plaintiff in the same position as he would have been had the contract been performed, but there is a wide divergence of opinion as to how this object may be achieved. Four different rules have been used by the courts in assessing damages for breach of a covenant to drill a well.": These are (1) the cost of drilling the well; (2) the value of the royalties, overriding royalties, oil payments, etc., that would have been received by the plaintiff if the well had been drilled; (3) the loss in market value of the retained interest resulting from the failure to drill, and (4) the value of the information that would have been received if the well had been drilled. Each of these rules will be separately considered.

\section{The Well Cost Rule}

In several jurisdictions, ${ }^{30}$ the courts have measured damages for failure to drill a well by permitting the promisee to recover the reasonable costs of drilling the well.:1 A leading case applying the cost of drilling rule is Fite v. Miller,"12 wherein the Supreme Court of Louisiana held as follows:

The plaintiff lost the right to have the well drilled by the defendant through his breach of the contracts. The value of this right or the act of performance

It Summers, Oil and Gas, para. 435, pp. 47-49.

4.5 Texas Pacific Coal and Oil Co. v. Barker (1928) 6 S.W. (2d) 1031.

4i This suggestion was followed in Cotiga Development Co. v. United Fuel Gas Co. (1962) 128 S.E. (2nd) 626 (W.Va.), in effect overruling Grass v. Big Creek Development Co. (1915) 84 S.E. 750 (W.V.a.)

ti Whlliams and Meyers, supra, n. 39 at 246

is Supra, n. 30 , at 280 .

11) Summers, Oil and Gas 17-20. See generally. Wllliams, Maxwell and Meyers, Cases and Materials on the Law of Oil and Gas 388-403 (1964); Hart, Damages and Other Relief for Breach of Express and Implied Covenants in Oil and Gas Leases and Drilling Agreements, (1956) Seventh Annual Institute on Oil and Gas Law and Taxation 47: Roberts, Damages-Measure of Damages for Breach of Contract to Drill Oil or Gas Well, (1956) 13 Washington and Lee Law Review 207; Fritz, "Underliquidated Damages as Limitation of Liability, (1954) 33 Texas Law Review 196: Discussion Note to Landauer v. Huey (1960) 13 O. \& G.R. 431 at 442-448; Comment by Flynn. (1953) 32 Texas Law Review 127.

so Louisiana, Oklahoma, Colorado, Kansas, Montana, Arkansas and New Mexico. See Annotation, 4 A.L.R. 3d 284 at 290.

$\therefore$ See generally, 5 Williams and Meyers, Oil and Gas Law Para. 885.1, pp. 590-596.

:- (1940) 200 So. 285. See Moses, The Measure of Damages for the Breach of a Drilling Obligation under a Mineral Lease in Louisiana, (1939) 14 Tulane L. Rev. 81. 
is the amount of money that it would have cost the defendant to drill the well when he should have done so. Therefore, it is our conclusion that the amount that it would have cost to drill the well at the time of performance furnishes a measure for determining the value of the loss or damage which the plaintiff sustained as a result of the defendant's unjustifiable nonperformance or breach of the contract, which deprived the plaintiff of his right to have the well drilled by the defendant.53

It is interesting to note that in this case the plaintiff recovered the full amount of the costs of drilling the well even though the evidence indicated that the well was likely to be a dry hole, and even though he had assigned a one-half interest in the land to the defendant.

It has been suggested that the difficulty of proving the amount of production under the loss of royalties rule has led the courts to adopt the well cost rule. Most courts would appear to agree that the cost of drilling rule is not always an accurate measure of the plaintiff's loss, but state that the rule can be readily ascertained and is substantially the equivalent in value of the act to be done. ${ }^{54}$ It has also been suggested that the well cost rule is a form of liquidated damages used to circumvent the difficulty of proof of damages under one of the other methods of assessing damages for breach of a covenant to drill a well.ss

Although the cost of drilling rule has the virtues of simplicity and ease of application, it has been criticized for the following reasons, namely:

(a) Under the well cost rule, the promisor can not reduce his damages by indicating that the well would be a dry hole, and as such, the plaintiff is overcompensated by receiving the costs of drilling the well, whereas if the well had been drilled, he would not have received any royalties. ${ }^{56}$ If the well would have been a producer, the plaintiff is also overcompensated if it can be proved that the royalties that he would have received are less than the costs of drilling. ${ }^{67}$

(b) In the usual case, the lessor or assignor does not contract for a well, but is an investor in a risk venture, and if the well is drilled, does not have any interest in the well, but has a reserved nonoperating interest in the proceeds of production of the well. On this basis, the well cost rule does not put the plaintiff in the same position as he would have been had the contract been performed. ${ }^{. s}$

(c) Another objection to the well cost rule is the fact that the plaintiff pockets the amount of the judgment and is not required to drill a well."0

(d) Ordinarily, in a situation where there has been a breach of a covenant to drill a well, the defendant either loses or surrenders his interest in the land, and if the plaintiff does use the damage money to drill a well, he will keep the proceeds of the entire production, and will be overcompensated, since he will receive more than if the defendant had drilled the well. ${ }^{\circ 0}$

53 Id. at 288

54 See Van Derhoof, Oil and Gas: Contract to Drill a Test Well: Measure of Damages for Breach, (1956) 3 U.C.L.A. Law Rev. 586 at 588 .

55 Scott, (1961) 9 Kansas Law Rev. 281 at 288.

56 Van Derhoof, supra, n. 54 at 589. 77 Rowe, The Measure of Damages for Breach of Contract to Drill a Test Well, (1944)

5s 5 Williams and Meyers, Oil and Gas Law 595.

50 Rowe, supra, n. 57 at 486 .

co Scott, (1961) 9 Kansas Law Rev. 281 at 283. 


\section{The Loss of Royalty Rule}

Texas has been the leading jurisdiction ${ }^{61}$ in holding that the measure of damages for failure to drill a well is the amount of royalties that the plaintiff would have received had the well been drilled.": In Guardian Trust Co. v. Brothers, ${ }^{1 ; 3}$ the sole issue was whether the reasonable cost of drilling the well was the correct measure of damages for breach of a covenant to drill a well. The agreed cost of drilling the well was in the sum of $\$ 8,000$. The Court of Civil Appeals of Texas rejected the well cost rule and adopted the loss of royalty rule as follows: ${ }^{13.1}$

If this well-established and fundamentally sound rule is to be applied to a contract for the drilling of an oil well, then the question arises, would $\$ 8,000$ have been the value to appellants of performance, or, stated differently, would the payment to appellants of $\$ 8,000$ put them in the same position that they would have been put had the well been drilled? The answer to that question is not difficult. The true and ultimate purpose of all parties to the lease was "the mutually profitable production of oil, gas, or other valuable mineral." Texas Co. v. Davis, 113 Texas. 321, 254 S.W. 304, 308, 255 S.W. 601. No other value to appellants than the value of the royalty was contemplated. The land was situated in an oil field and three wells had been drilled on this tract a few years before this lease was executed. The royalty was one-eighth of the oil and a like proportion of the proceeds of the sale of gas. Its value might have been substantially more than $\$ 8,000$ and it might have been substantially less. The only way to put appellants in the position they would have been put by performance would be to award them damages measured by the value of their royalty. The burden was upon them to establish that value, but they offered no evidence thereof. There is no more reason to fix that value at $\$ 8,000$ than there is to fix it at $\$ 10,000$ or $\$ 2,000$. To do so would be to hold that the measure of damages for the breach of a contract is not the value of performance to the obligee, but is the cost of performance to the obligor.

Suppose these appellants had been the owners of a vacant lot in the town of Desdemona, near which the land covered by this lease is situated, and had entered into a contract with appellee, under the terms of which appellee agreed to erect a building thereon according to certain specifications and to pay appellants one-eighth of the gross revenues to be derived from renting the building, and that the contract had provided that appellee should have the right to remove the building at the expiration of the lease, placing the land in as good condition as it was before the lease was given. Then suppose that appellee had failed to erect the building. Would it be seriously contended that appellant's measure of damages for the breach of that contract would be what it would have cost to erect the building? We think not. The loss or injury actually sustained by the obligee, rather than the cost of performance by the obligor, is the proper measure of damages for the breach of a contract. When that well-established rule is departed from, compensatory damages become either punitive damages, because too much, or inadequate damages, because too little, and the fundamental purpose of compensatory damages is lost sight of. We can see no just reason for departing from the well-established rule of law for measuring damages simply because the contract relates to the sinking of an oil well. The fact that the nature of the contract is such as to render it impossible to ascertain with mathematical accuracy the exact amount of the damages suffered by the lessor should not operate to change the rule. The parties knew that difficulty inhered in the subject about which they were contracting but chose not to stipulate for liquidated damages.

The loss of royalty rule as a measure of damages for breach of a covenant to drill a well would seem to comply with the object of placing the plaintiff in the same position he would have been had the well been drilled, and seems to best represent the intention of the parties, in that what the promisee bargained for was not a hole in the ground, but for the royalty that would be produced from the hole in the ground.

(i) The loss of royalty rule has also been adopted in California and Kentucky. See 5 Williams and Meyers, Oil and Gas Law Para. 885.2, p. 600.

6: See generally, Id. at 596-601.

(i3 (1933) 59 S.W. $2 d 343$ (Tex. Civ. App.).

04 Id. at $345-346$. 
The loss of royalty rule has been criticized for the following reasons, namely:

(a) It is extremely difficult for the plantiff to prove what the well would have produced had it been drilled." In the absence of such proof, the plaintiff is entitled to nominal damages only. ${ }^{60 i}$

(b) To reduce the amount of damage, the defendant is permitted to show that the well would have been a dry hole, and as such, the plaintiff is for all practical purposes without a remedy to enforce the promise and the promisor who breached his obligation gets off scot-free."it

(c) A criticism from the defendant's point of view is that the plaintiff is permitted to recover double royalties if production is later obtained from the premises. ${ }^{88}$

Commenting on the criticisms of the loss of royalty rule, Williams and Meyers state as follows: ${ }^{\text {: }}$

In our view, this objection is not a sufficient basis for overturning the lostroyalty rule and replacing it with the cost-of-drilling rule. In the first place, if it is true that the well would be a dry hole, then lessor has lost nothing from the failure to drill it. In the second place, the cost of drilling the well does not seem to be the benefit the promisee bargained for. In the third place, there are other devices to secure performance of the promise, such as forfeiture and termination clauses and liquidated damages clauses. Lastly, the speculative interest the lessor or assignor had in the drilling of the well can be protected by a damage recovery, at least under one line of authority. We consider this measure of recovery in the next section. [Value-of-retained-interest rule.]

3. The Loss of Market Value Rule

Another method of measuring damages for breach of a covenant to drill a well is the loss in market value of the plaintiff's retained interest as a result of the defendant's failure to drill. ${ }^{\circ 0}$ In some cases, the plaintiff has contended that the market value of his retained interest would have increased, or alternatively, would not have decreased, if the well had been drilled, and accordingly, has claimed as damages for the failure to drill the well the difference in the market value of his interest when the well was not drilled and the value of his interest if the well had been drilled.

In the case of Whiteside v. Trentman,;1 a decision of the Commission of Appeals of Texas, the issue was whether the amount which the retained leases would have increased in market value during the drilling of the well was the proper measure of damages sustained by the plaintiff. In this case the plaintiff assigned certain leases in a large block to the defendant, who agreed to drill two wells on the assigned acreage. The defendant drilled a dry hole and refused to drill the second well. The plaintiff did not retain any interest in the leases assigned and the jury found that the object of the plaintiff was to create an increased demand and market value for the leases retained by him.

The jury further found that if the defendant had drilled the well it would have been a dry hole, but found that if the defendant had begun

i:-i Scott, (1961) Kansas Law Rev. 281 at 284.

j;: Van Derhoof, (1956) 3 U.C.L.A. Law Rev. 586 at 589.

i7 5 Williams and Meyers, Oil and Gas Law 601.

f; Rowe, (1944) 22 Texas Law Rev. 481 at 485 . See supra, n. 31, for a suggested solution to the problem of double royalties.

;0 5 Williams and Meyers, Oil and Gas Law 601

i) See generally. Id. at 601-606.

i) (1943) $170 \mathrm{~S}$. W. $2 \mathrm{~d} 195$. 
drilling the well, the demand for, and market value of, the leases owned and retained by the plaintiff would thereby have been increased.

The court found that the plaintiff had three courses open to him. Firstly, he could have sold all of his retained leases and realized the profit from the enhanced value thereof caused by the drilling; secondly, he could have sold part of the leases taking his chances on a greater profit on the remainder if the well was a producer; and thirdly, he could have retained all of the leases and "ridden the well down", gambling on a greater profit if the well was successful, and realizing no profit if the well was a dry hole. ${ }^{i 2}$

The court held that the plaintiff could recover the loss of market value as damages for breach of the covenant to drill a well, provided that he could satisfy the court that he would have sold the retained leases or some of them. There was no finding by the jury on the question of whether or not the plaintiff would have sold his leases while the drilling was in progress, and the case was remanded on this basis.

It is to be noted that the plaintiff did not retain any interest in the assigned leases, and as such, this decision does not affect the decision in Guardian Trust Co. v. Brothers, ${ }^{, 3}$ holding that in Texas, if the plaintiff retains an interest, the measure of damages for breach of an express covenant to drill a well is the amount of the royalties that would have accrued if the well had been drilled. The case is cited for its excellent explanation of loss of market value as a measure of damages, and is cited to show that loss of market value could be an appropriate measure of damages for breach of a covenant to drill a well where the plaintiff has retained an interest, if the court is prepared to find that such damages are the direct and necessary result of the defendant's breach of contract, or, the court is prepared to find that the defendant had express knowledge of the plaintiff's intention to sell the retained interest.

The loss of market value of the retained interest test has been applied as the proper measure of damages for breach of a contract to drill a well by the Fifth Circuit Court of Appeals in Cockburn v. $O^{\prime} M_{e a r a}{ }^{i 4}$ and by Mr. Justice Riley in Albrecht v. Imperial Oil Limited,"i wherein he granted the plaintiff lessor damages consisting of the value that his royalty could have been sold for if the promised well had been drilled.

Under the rule in Whiteside v. Trentman, the plaintiff can recover the full amount of the increase in market value only if he can show that he would have sold all of his retained interest while drilling was under way. If he cannot show that he would have sold any of his retained interest, he will not recover any damages. But what happens if it is shown that he would have sold only a part of his retained interest?

If the well would have been a producer, the plaintiff should recover the profit that he would have made on the interest that he would have sold, since the same would not have declined in value if oil had been discovered. But if the well would have been dry, Rowe suggests that the plaintiff can recover only the net amount lost by

72 Id. at 196.

73 (1933) 59 S.W. 2d 343 (Texas Civ. App.).

it (1946) 155 F. $2 d 340$ (5th Cir.). See also Ganzenbacher v. Howard Clay Oil Co. (1922)

73 (1957) 21 W.W.R. (N.S.) 560 . 
reason of the defendant's breach, that is, what he would have gained from the sale of the interest that he would have sold, less the amount he would have lost because of the decline in market value of the interest that he would have retained. He concludes by stating that if the loss on the interest retained would have been greater, he would receive nothing at all. ${ }^{76}$

It is respectfully submitted that this suggestion is a limitation on recovery by the plaintiff which is not warranted by the realities of the situation. The object of damages is to place the plaintiff in the same position as he would have been had the well been drilled, and as such, if the plaintiff, during the drilling of the well had sold one half of his retained interest for an increase in market value of $\$ 50,000$, he would still have this amount in his pocket even if the well had been dry and he had suffered a theoretical $\$ 50,000$ loss in market value on the retained one half interest.

Although in theory the loss of market value rule best achieves the object of damages for breach of contract, that is, to place the plaintiff in the same position as he would have been had the contract been performed, the rule has been criticized for its practical limitations as follows:

(a) The difficult practical problem of proving the truth of the plaintiff's intention to sell the interest as the well was being drilled, and the amount of the retained interest that he would have sold.:-

(b) The problem of establishing the increase in market value of the retained interest if the well had been drilled.

(c) The fact that some courts do not, as do the Texas Courts," require proof that the plaintiff would have sold his retained interest and award damages on evidence of an opportunity to sell. ${ }^{-9}$ It is submitted that in such a situation if it had been the intention of the plaintiff to ride the well down and if the well would have been a dry hole, the plaintiff is getting a windfall in such a recovery. ${ }^{80}$

\section{The Value of Information Rule}

A fourth method of measuring damages for breach of a covenant to drill a well is the value of the services rendered in furnishing the geological information disclosed by the drilling of the well."1 This measure of damages has been applied by the courts in cases where the plaintiff agrees to lease or assign a lease to the defendant in consideration of the defendant's promise to drill a well in an area where the plaintiff has retained other mineral properties, and where the contract provides that the defendant will furnish the plaintiff with a log of the well and such other geological information as may be discovered by the drilling. These "bottom hole" and "dry hole" contribution agreements are used by the oil and gas industry in undeveloped areas.

if Rowe (1944) 22 Texas Law Rev. 481 at 843-484.

$7 i 5$ Williams and Meyers, Oil and Gas Law 604 .

is Whiteside v. Trentman (1943) 170 S.W. 2d 195; Riddle v. Lanier (1941) $145 \mathrm{~S} . \mathrm{W}$. 2d 1094.

io Sanzenbacher v. Howard-Clay Oil Co. (1922) 283 Fed. 13 (8th Cir.) and Cockburn v. O'Meara (1946) 155 F. $2 d$ d 340 (5th Cir.). In Canada, see Albrecht v. Imperial Oil Limited (1957) 21 W.W.R. 560.

so 5 Williams and Meyers, Oil and Gas Law 605.

s1 See generally, Id. at 606-609. 
A leading case applying the value of information rule is the decision of the Tenth Circuit Court of Appeals in Hoffer Oil Corporation v. Carpenter. ${ }^{82}$ In this case the plaintiff assigned certain leases to the defendant in exchange for a cash consideration, a covenant to drill a well on the assigned acreage and a provision that the plaintiff was to have complete access to information about the drilling of the well. The plaintiff sued for breach of the covenant to drill, alleging that he had suffered damage by the defendant's failure to drill, because the well if drilled would have provided him with information which would have been of great value to him in establishing the productive or unproductive quality of his retained land.

The court held that the cost of drilling rule is not the proper measure of damages in a situation where the plaintiff retains no interest in the land upon which the well is to be drilled, because the plaintiff would have no interest in the well when drilled and all production therefrom would have belonged to the defendant. The court also rejected the reasonable value of the leases assigned as the measure of damages ${ }^{\times 3}$ and held that the plaintiff's damages were to be measured by the value to the plaintiff of the information from the well. The court stated as follows: ${ }^{84}$

We conclude that the value of such services is what a reasonable person owning land adjacent to the lands on which another proposes to drill such a test well, similarly situated and of similar oil-bearing potentialities as the land of the parties in the instant case, would ordinarily pay by way of contribution to the cost of such test well for the log of such well and the geological information which the drilling thereof would disclose. While a witness should not be permitted to speculate or conjecture as to possible or probable damages, still the best evidence obtainable, under the circumstances, is receivable, and this is often nothing better than the opinion of well-informed persons.

There would appear to be no objection to the value of information rule as the proper measure of damages in the "bottom hole" or "dry hole" contribution situation. The promissee has contracted for certain information and if another person is prepared to drill a well in the vicinity of the plaintiff's retained acreage, he can receive this information by making a contribution, in the amount of the damages awarded, to the costs of drilling that well and thereby be in the same position as if the defendant had performed his contract. However, if it is difficult to prove what is customarily paid for the information desired, or if it is not possible to find another person to drill on this basis, then the measure of damages should be the cost of drilling the well, as this is the only way that the plaintiff will receive his information.

\section{G. CATEGORIES OF BREACH OF A COVENANT TO DRILL}

\section{A WELL}

As discussed above there is a choice of rules for determining damages for breach of a covenant to drill a well. It is submitted that a more logical choice of remedies can be made if one analyzes the factual situations in which a breach of covenant to drill a well has occurred in terms of the object of damages for breach of contract of placing the

82 (1929) 34 F. 2d 589 (10th Cir.), noted in (1930) 39 Yale Law Journal 431. See also Bu-Vi-Bar Petroleum Corp. v. Krow (1931) 47 F. 2d 1065 (10th Cir.), and Atlantic Oil Producing Co. v. Masterson (1929) 30 F. 2d 481 (5th Cir.).

83 This would have constituted rescission of the contract and not damages for breach of the contract.

y. (1929) 34 F. 2 d 589 at 593. 
plaintiff in the same position as he would have been had the contract been performed. There are four categories of breach of a covenant to drill a well, ${ }^{85}$ namely: (1) where the plaintiff has employed a drilling contractor to drill a well on the plaintiff's land and the drilling contractor has no interest in the well; (2) where the defendant has contracted to drill a well in which the plaintiff will have an interest with the defendant on land in which the defendant is a co-owner with the plaintiff; (3) where the defendant has contracted to drill a well in which the plaintiff will have no interest on land in which the plaintiff has reserved a royalty interest; and (4) where the defendant has contracted to drill a well in which the plaintiff will have no interest on land in which the plaintiff has no interest. Each of these factual situations will be discussed separately.

\section{Defendant has no interest in the well on the plaintiff's land}

This category is represented by the employment by the plaintiff of a drilling contractor to drill a well on the plaintiff's land. ${ }^{\mathrm{N} i \mathrm{i}}$ If the defendant driller breaches the Drilling Contractsi the courts have applied the rule of damages for breach of a construction contract that the plaintiff is entitled to recover the cost of completing the building minus the contract price, or that part of the contract price, if any, remaining unpaid. ${ }^{8 \mathrm{I}}$ In addition, the plaintiff may recover damages for loss of sales of oil, drainage or payment of delay rentals, if he can establish that the defendant had knowledge of these circumstances at the time that the Drilling Contract was entered into. ${ }^{80}$

Analyzing this situation in terms of the test of "what did the plaintiff bargain for", it can be seen that the well cost theory is an appropriate measure of damages for this category. The plaintiff bargained for a well on his land, and the only way to place him in the same position as he would have been had the contract been performed is to give him the means of getting his well, i.e., the additional costs, if any, of drilling the same. This measure of damages for breach of a Drilling Contract was applied in Covington Oil Co. v. Jones ${ }^{30}$ and by the Appellate Division of the Supreme Court of Alberta in Fidelity Oil and Gas Co. v. Janse Drilling Co. ${ }^{11}$

\section{Defendant has an interest in both the land and the well}

In a Farmout Agreement, ${ }^{92}$ the plaintiff, in consideration of the defendant's promise to drill a well, agrees to convey to the defendant an interest in an oil and gas lease. As additional consideration for the

85 Maxwell, Damages for Breach of Express and Implied Drilling Covenants, (1960) 5 Rocky Mountain Mineral Law Institute 435 .

86 Id. at 442-444.

87 For an example of a Drilling Contract, see 1 Lewis and Thompson, Canadian Oil and Gas Div. C. Form A $16(\mathrm{a})$.

88 Mayne and McGregor on Damages 485 (12th Ed.). Although not common in the oil and gas industry, a discussion of damages for breach of a covenant to drill a well would not be complete without reference to breach of the drilling contract by the promissee. If the driller is suing the owner for damages for breach of a covenant to drill a well. drill a well, the method of calculating damages is again determined by reference to damages for breach of a construction contract, and the driller will recover the loss of the expected profit, which is the difference between the contract price and the cost to the driller of carrying out the work. For an excellent discussion of damages for breach of a Drilling Contract by the owner, see Maxwell, supra, $n$. 85 at $436-439$. 89 Maxwell, supra, n. 85 at 442

90 (1922) 244 S.W. 287 (Tex. Civ. App.).

01 (1916) 27 D.L.R. 651.

92 For an example of a Farmout Agreement, see 1 Lewis and Thompson, Canadian Oil and Gas Div. C, Form B.2(a). 
transfer, the plaintiff can retain an overriding royalty, an oil payment, a net profits interest, an undivided share of the working interest, a carried interest, an option to acquire some interest, operating or nonoperating, in the assigned property, or the right to obtain information with respect to the drilling of the well. ${ }^{33}$

This category is concerned with a Farmout Agreement in which the plaintiff retains an operating interest such as a working interest or a carried interest. ${ }^{04}$ Dealing firstly with the situation of a Farmout Agreement wherein the plaintiff retains a working interest, for example, a $40 \%$ working interest, and analyzing the same in terms of "what did the plaintiff bargain for", it is submitted that the plaintiff, if he is liable to put up his share of the drilling expenses whether the well is a producer or not, bargained for a $40 \%$ interest in a well. He did not bargain for a risk free chance to share in the proceeds of production from the well, since he has agreed to put up his share of the expenses. As such, it is submitted that the only way to place such a plaintiff in the same position as he would have been had the contract been performed is to give him the share of the costs of drilling the well that the defendant was required to contribute, in our example, $60 \%$ of the drilling costs.

The question of a proportionate reduction of drilling costs was raised in Fite v. Miller. ${ }^{95}$ The Court refused to reduce the costs on the basis that the right to have the well drilled is worth what it would cost to drill the well and the defendant cannot reduce his damages on the grounds of his breach of contract. ${ }^{36}$ In Fite v. Miller the plaintiff had reserved a $50 \%$ carried working interest, and as such, this case does not deny recovery of a proportionate part of the drilling costs in an appropriate situation, such as the situation where the plaintiff has retained a participating working interest as outlined above. ${ }^{0:}$

Turning now to the situation where the plaintiff reserves a contingent working interest ${ }^{\mathrm{ax}}$ or a carried working interest, ${ }^{n 9}$ it is suggested, that although the plaintiff has an interest in both the land and the well, that what the plaintiff has really bargained for is a risk-free chance to share in the proceeds of production of the well. How are we to put such a plaintiff in the same position as he would have been had the contract been performed?

It is unlikely that such a plaintiff can prove damages under the loss of royalty rule, but if he can, it is submitted that he should recover

032 Williams and Meyers, Oil and Gas Law Para. 432, p. 487-489.

94 The other types of interests that can be retained will be discussed in categories 3 and 4 , infra.

95 (1940) 200 So. 285.

96 Id. at 289 .

97 See also Maxwell, (1960) 5 Rocky Mountain Mineral Law Institute 434 at 451 and 457 , wherein he suggests that the plaintiff can recover a proportionate part of the drilling costs.

os Some Farmout Agreements contain the following clause:

"UPON completion of the test well and in the event of production in commercial quantities being encountered in, and such production being taken from the test well, Farmor shall and wlll reimburse Farmee to the extent of Fifty percent $(50 \%)$ of the actual cost of all equipment and materials actually used in completing said test well except for casing, cement used for setting same, tubing. Control Head (Christmas Tree) and the cost of fittings required for their proper installation on the well, and upon such payment Farmor shall have and own a fifty percent $(50 \%)$ interest in the understood further that if production in commercial quantities shall not be obtained. the entire costs of completion and of the proper abandonment of the said test well the entire costs of completion and

90 For an example of a carried interest see Pine Pass Oil and Gas v. Pacific Petroleums Ltd. (1968) 70 D.L.R. 196. 
the amount of production that would have been attributed to his operating interest had the well been drilled; in the case of a carried working interest this would require proof of production in excess of the costs of drilling. It is submitted that recovery of damages under the loss of royalty formula is recovery of damages in the ordinary course of things within the meaning of the first rule in Hadley v. Baxendale. ${ }^{100}$

Is there any other rule under which such a plaintiff can recover? As stated above, such a plaintiff is not in the position of a party to a Drilling Contract but is in the position of an investor in a risk enterprise in that he has not bargained for the drilling of a well, but has bargained for a risk free chance to share in the proceeds of production. What he has lost then is the value of.his opportunity to make a profit and he should recover damages under the loss of market value rule.

In order to grant damages for loss of market value, the court must find that damages for loss of market value are damages which occur in the ordinary course of things, and as such, the defendant at the time of entering the Farmout Agreement, knew or should have known that the plaintiff intended to sell his retained interest. Alternatively, the court can grant damages for loss of market value if it holds that such damages are not damages which occur in the ordinary course of things, but that at the time of entering the Farmout Agreement, the plaintiff communicated to the defendant his intention to sell his retained interest. It is submitted that speculation is a characteristic of the oil and gas industry, and as such, damages for loss of market value are in the ordinary course of things, and can be recovered by the plaintiff under the first, rather than the second, rule in Hadley v. Baxendale.

How are these damages to be calculated? It is respectfully submitted that despite the practical problems of proof, the courts should require evidence that the plaintiff would have sold his interest. If the plaintiff would not have sold his interest, then he will be compensated under the loss of royalty rule discussed above. If he would have sold his retained interest during the drilling of the well, he is entitled to recover the amount that his retained interest would have increased in market value due to the drilling of the well. If, because of the difficulties of proof, the courts will not require evidence that the plaintiff would have sold, but simply require evidence of an opportunity to sell, it is submitted that the plaintiff should not recover in a situation in which he has received a reasonable offer of purchase and has rejected the same, as the rejection is evidence of his intention to "ride the well down".

\section{Plaintiff has a royalty interest in the land}

This category is represented by the following situations, namely: (1) a Farmout Agreement in which the plaintiff has reserved an overriding royalty, an oil payment, a net profits interest, or an option to acquire an operating or non-operating interest; (2) an assignment in which the plaintiff has reserved an overriding royalty, or (3) a lease in which the plaintiff has reserved a royalty interest.

It is submitted that in each of these cases, the plaintiff has bargained for a risk free chance to share in the proceeds of oil and gas production.

100 The plaintiff in the participating working interest situation discussed above should also recover damages under the loss of royalty rule. 
As such, the plaintiff is entitled to recover the amount of the royalties (or proceeds of production) that he would have received had the well been drilled, and is entitled to recover the loss in market value of his retained interest as a result of the defendant's failure to drill. Since these cases are similar to the co-ownership situation discussed under category 2 above, it is not necessary to comment further on the methods of assessing damages.

\section{Plaintiff has no interest in the well or in the land}

This category is represented by the situation in which the plaintiff assigns a lease to the defendant in consideration of the defendant's promise to drill a well on the assigned property and in consideration of the defendant's promise to provide the plaintiff with the geological information disclosed by the drilling of the well. The plaintiff is primarily interested in the information he will receive from the drilling of the well and does not retain any interest in the property assigned.

It is submitted that such a plaintiff has bargained for the information that he will receive from the drilling of the well, and that the only way to place him in the same position as he would have been had the contract been performed, is to provide him with this information. One of the ways of providing him with this information is to award him damages in the amount that plaintiff would be required to contribute, in return for the information, to the drilling of a well by another person in the same area. If another person is not prepared to drill on this basis, the only way that the plaintiff can receive this information is by drilling the well himself, and as such, in these circumstances, he should be awarded the costs of drilling the well as damages for breach of contract.

It is further submitted that the reason that the plaintiff has entered into this type of an agreement is to assess the productivity of his retained land, and as such, he is unlikely to sell his retained acreage during the drilling of the well. On this basis, damages for loss of market value would not be in the ordinary course of things, and the plaintiff could only recover damages for loss of market value if, at the time of the contract, he advised the defendant of his intention to sell his retained acreage during the drilling of the well.

\section{H. CANADIAN DECISIONS}

One of the early Canadian cases on breach of a covenant to drill a well is Kranz v. McCutcheon, ${ }^{111}$ wherein the defendant covenanted to drill and equip at least five wells. The defendant drilled two wells and refused to drill any more wells. In assessing the damages that the plaintiff was entitled to recover for the defendant's failure to drill five wells, Mr. Justice Masten said as follows: ${ }^{102}$

The two wells which were bored proved failures. The general evidence was that, while no one could forecast with certainty what the result of boring three more wells would be, yet the general reputation of the oil-field had greatly declined. At the same time, it was possible that, if the remaining wells were bored, oil would be struck in paying quantities.

The broad, general rule is, that damages which are uncertain, contingent, and speculative in their nature, cannot be made a basis of recovery; but this rule against the recovery of uncertain damages is directed against uncertainty as to the cause rather than as to the extent or measure. 
Mr. Justice Masten concluded by granting judgment declaring that the defendant had breached the contract, "that substantial damages are recoverable in respect thereof," and referred the action to the Local Master to assess such damages. ${ }^{103}$

The Court of Appeal ${ }^{104}$ directed that the judgment be varied by striking out the words "substantial damages in respect of", and substituting in their place the words "the damages, if any, sustained by reason of", and further varied by directing that the reference as to damages shall be at large, and that the Referee shall not be bound by the opinion of Mr. Justice Masten as to the basis on which damages are to be computed. ${ }^{108}$

Although this decision does not define the measure of damages for failure to drill a well, it is submitted that the statement that the "reputation" of the oil field had declined, would indicate that market value is to be taken into account in assessing damages for breach of a covenant to drill a well.

Another early Canadian case on breach of a covenant to drill a well is Carson v. Willitts, ${ }^{101}$ wherein the defendant, in consideration of an assignment of a one-half interest in the plaintiff's leases, undertook to drill three wells. The defendant drilled one well and refused to drill the other two wells. On a reference, the local Master assessed damages on the basis of what it would cost the plaintiff to drill the two wells. The Appellate Division of the Ontario Supreme Court held that the cost of drilling was not the proper basis on which to measure damages for breach of a covenant to drill a well, and continued as follows: ${ }^{10 i}$

Then what is the basis on which this Court should now direct the damages be assessed? In my opinion, what the plaintiff lost by the refusal of the defendant to bore two more wells was a sporting or gambling chance that valuable oil or gas would be found when the two further wells were bored. If the wells had been bored and no oil or gas of value had been found, the effect would be that the plaintiff has lost nothing by the refusal of the defendant to go on boring. On the other hand, if valuable oil or gas had been discovered, by the boring of these two wells, he had lost substantially. It may not be easy to compute what that chance was worth to the plaintiff, but the difficulty in estimating the quantum is no reason for refusing to award any damages.

The Court of Appeal held that the plaintiff is entitled to damages for the "loss of the chance that valuable oil or gas might have been discovered" if the defendant had drilled the additional wells. ${ }^{103}$ How is the value of this "chance" to be determined? It is submitted, that in terms of the methods of assessing damages for breach of a covenant to drill a well discussed in this paper, the most appropriate way to measure the value of this "chance", is by the amount that a bona fide purchaser would have offered for the said "chance" if the wells had been drilled, in short, on the basis of the loss of market value rule.

In Kinkel v. Hyman, ${ }^{10 "}$ a decision of the Supreme Court of Canada in an action for damages for breach of an option to repurchase shares, Mr. Justice Crocket commented on the case of Carson v. Willitts as follows: ${ }^{110}$

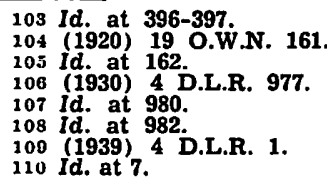


For my part I can find no authority in either Chaplin v. Hicks ${ }^{111}$ or Carson v. Willitts justifying any Court in awarding any more than a nominal sum as damages for the loss of a mere chance of possible benefit except upon evidence proving that there was some reasonable probability of the plaintiff realizing therefrom an advantage of some real substantial monetary value. Indeed the above quotations from Chaplin v. Hicks and the decision in Carson v. Willitts seem to me to point to the contrary.

In terms of our discussion of the loss of market value rule, this comment would indicate that the plaintiff in an action for breach of covenant to drill a well will recover nominal damages only, unless he establishes that there was a reasonable probability that he would have received a valuable offer for his interest if the defendant had drilled the well.

In Cotter v. General Petroleums Ltd., ${ }^{112}$ the plaintiff was the assignee of a petroleum and natural gas lease which provided that the lessee would drill a well on the leased premises within six months. The lease further provided that upon payment of the sum of $\$ 1,000$ the drilling commitment could be extended for an additional six months. The plaintiff entered into an Agreement with the defendant, whereby the defendant was granted an option to earn a Sublease of the leased premises. The option was to be exercised by the defendant commencing the drilling of a well within the six month period. In a later clause in the said Agreement, the defendant covenanted to exercise the option within the time and in the manner designated in the Agreement. In the form of Sublease attached to the said Agreement, the plaintiff reserved a $21 / 2 \%$ gross overriding royalty and a $50 \%$ net profits interest.

The defendant refused to drill the well and the plaintiff sued for damages for breach of covenant to drill a well. In the Trial Division, ${ }^{113}$ Mr. Justice McLaurin held that the Agreement required the defendant to commence the drilling of a well within the six month period and held the defendant in breach of his obligation. ${ }^{114}$ The geological evidence was not too favourable, but the chance of production could not be completely ruled out; the estimated cost of drilling the well was $\$ 53,500$. With respect to the measure of damages for breach of a covenant to drill a well, Mr. Justice McLaurin concluded as follows: ${ }^{115}$

I am strongly influenced by the reasoning in those American cases which fix the cost of drilling as the criterion, and from the reports available was unable to confirm the statement in the one Texas case that the preponderance of authority now rejects the cost of drilling theory. I can conceive of circumstances in which it might not be an appropriate basis, but in territory that is untested how can a party, such as the plaintiff here, secure adequate redress for a breach of the drilling covenant, except by being put in the position to pay some other to do that which the defendants covenanted to do?

It seems to me that on a fair analysis of the contract the defendants were let in on what then looked very attractive, let in on something that cost a substantial amount, and that it was assumed that the joint venture, by reason of the defendant's covenant, was in as good a position as if the defendants had contributed fifty thousand odd dollars to the partnership treasury. Can I award any amount other than $\$ 54,500$, the additional $\$ 1,000$ being for the amount necessarily paid the head lessor for an extension of time for drilling? I do not think any additional damages would be warranted. If production is secured, the plaintiff might win rather handsomely, as the defendants by their breach no longer have an interest in the acreage. Accordingly, it seems to me that the plaintiff receives ample redress if he is paid the cost of drilling the well. But as there is a gambling chance of production, should that chance be measured in

111 (1911) 2 K.B. 786.

112 (1950) 4 D.L.R. 609 .

113 (1949) 1 W.W.R. 193 .

114 Id. at 198.

115 Id. at 207. 
money, and to the extent thereof a deduction be made from the estimated drilling cost? I must confess that I do not know how to go about measuring that chance, and feel that any figure I might arrive at would be arbitrary and capricious. I would have absolutely no confidence in any amount that I might name. The expert evidence the defendants themselves led would suggest that the sum should be negligible, and even the evidence led by the plaintiff leaves the outcome of drilling wrapped in uncertainty.

In the Appellate Division, ${ }^{11:}$ Chief Justice Harvey held that there was no express covenant by the defendant to drill a well. He held that the Agreement sued on was an agreement for an option only, that the later covenant which provided that the defendant would exercise the option, completely nullified the choice given by the earlier covenant, and as such, must be rejected as repugnant and void. The action being founded on the covenant that the defendant would exercise the option, the action failed.11 On this basis, Chief Justice Harvey did not consider whether the proper principle had been applied in determining damages for breach of a covenant to drill a well.118

In the Supreme Court of Canada, ${ }^{119} \mathrm{Mr}$. Justice Kerwin ${ }^{120}$ held that there was no repugnancy between the clauses, and as such, the defendant was bound to commence the work of drilling a well, but that there was no obligation on the defendant to continue the drilling. ${ }^{121} \mathrm{He}$ held that damages should be calculated not on the basis that the covenant was one to drill a well, but on the basis that the covenant was one to commence a well. There being no evidence of damages other than the $\$ 1,000$ paid by the plaintiff for a further six months renewal of the head lease, Mr. Justice Kerwin awarded damages for the said sum of $\$ 1,000$. $^{122}$

Mr. Justice Cartwright ${ }^{12: 3}$ also found that there was no repugnancy between the provisions of the Agreement, but held that the defendant was bound not only to commence but to complete the drilling of the well, because commencement of drilling, coupled with a failure to carry on, would not result in any benefit to the plaintiff, but would result in forfeiture of the lease. ${ }^{12+4} \mathrm{Mr}$. Justice Cartwright then considered on what principle and at what amount the damages should be assessed. He rejected the cost of drilling as the proper measure of damages on the basis that the cost of drilling is the proper measure of damages in cases where the consideration to be given for the drilling had actually passed to the defendant, ${ }^{11 ;}$ and concluded as follows: ${ }^{12 i}$

The appellant did not seek to put his case on the ground that by reason of the breach he stood to lose the head lease, but rather that he intended to make and was in process of making other arrangements to have a well drilled. In my view, the proper measure of his damages under the circumstances of this case is the difference between the value to him of the consideration for which the respondents agreed to drill the well and the value to him of the consideration which, acting reasonably, he should find it necessary to give to have the well drilled by others. I am unable to find in the record evidence on which the damages can be assessed on this basis. It is well settled that the mere fact that damages are difficult to estimate and cannot be assessed with certainty does

116 (1949) 3 D.L.R. 634.

117 Id. at $637-638$.

118 Id. at 636 .

$11 \mathrm{~s}(1950) 4$ D.L.R. 609.

120 With whom Chief Justice Rinfret concurred.

$121(1950) 4$ D.L.R. 609 at 613 .

122 Id. at 615 .

123 With whom Mr. Justice Fauteux concurred. Mr. Justice Locke adopted the views of the Court of Appeal and dissented on the issue of repugnancy.

124 (1950) 4 D.L.R. 609 at 626-627.

12 Id. at 628 .

120 Id. at $628-629$. 
not relieve the party in default of the necessity of paying damages and is no ground for awarding only nominal damages, but the onus of proving his damages still rests upon the plaintiff. The evidence of the appellant given at the trial on December 3,1948, was to the effect that he and his associates had been and still were in negotiation with an oil company but that they had found themselves forced to deal with the whole 160 acres instead of 80 acres. As Mr. Steer pointed out there is no evidence as to the terms offered by such company and such terms may have been more or less advantageous to the appellant than those contained in the contract sued on. It would have been open to the appellant to have delayed bringing his action until the completion of his arrangements to have the well drilled by which time the damages, if any, would have been more easily ascertained. But the appellant, as he had a right to do, brought his action to trial before that date. There is no complaint that any evidence he wished to tender in support of his claim for damages was rejected, nor was there any request made for a reference to fix the damages and the case must be decided upon the evidence in the record. In my view, there is no evidence to support an award of damages other than the $\$ 1,000$ paid for that extension of the time for drilling. If the evidence showed that the appellant had suffered or must of necessity suffer substantial damages, over and above the $\$ 1,000$ already mentioned, by reason of the respondents' breach, the Court should, I think, seek some means of arriving at a proper assessment, but in my view the most that the evidence can be said to indicate is a probability of some loss. It is possible that there has been no loss at all.

Analyzing this decision in terms of the methods of assessing damages for breach of a covenant to drill a well discussed in this paper, it can be seen that the cost of drilling method was rejected, that there was no evidence of losses within the loss of royalty rule, and that the value of information rule was not applicable. With respect to the loss of market value rule, there was no evidence that the property would have increased in market value if the well had been drilled, nor was there any evidence that the plaintiff would have sold his retained interest. In fact, the plaintiff chose to present his case on the basis that he was retaining his interest in the lease, and that he intended to make, and was in the process of making, other arrangements to have a well drilled.

On this basis, the way to place the plaintiff in the same position that he would have been had the contract been performed, is to award him the extra consideration that he is required to give to have the well drilled by somebody else. There being no evidence of the terms on which a third party was prepared to drill a well, other than the fact that the plaintiff was forced to deal with the whole 160 acres instead of 80 acres, the Supreme Court of Canada awarded damages for the sum of $\$ 1,000$ only. The special circumstances of the plaintiff being required to pay $\$ 1,000$ to renew the head lease was known to the defendant, and as such, the plaintiff recovered the sum of $\$ 1,000$ under the second rule of Hadley v. Baxendale.":-

It is submitted that Mr. Justice Kerwin's test of extra consideration is similar to the test of loss of market value discussed above, i.e., how else can one assess the depreciation in the value of the retained interest, but that the test of extra consideration as set out by Mr. Justice Kerwin is to be applied to the market value at a different time than the loss of market value test. There are three different points in time to be considered in applying the loss of market value test, namely:

(a) The highest market value of the property is at the time when the well would have been drilling;

127 Id. at 615 . 
(b) The intermediate value of the property is at the time that the contract containing the covenant to drill was entered into;

(c) The lowest market value of the property is at the time of the breach of the covenant to drill a well.

It is submitted that the loss of market value test awards damages in an amount which is the difference between the market value at the time the well would have been drilling and the market value after breach of the covenant to drill a well, whereas the test of extra consideration awards damages in an amount which is the difference between the market value at the time the contract containing the covenant to drill a well was entered into and the market value after breach of the covenant to drill a well. As can be seen, damages are higher under the loss of market value test, but the loss of market value test requires proof of the increase in market value due to the drilling of the well and evidence of an intention to sell.

On this analysis, there is nothing in the decision of the Supreme Court of Canada in the Cotter case to prohibit a court, in a proper situation, from awarding damages for breach of a covenant to drill a well on the basis of loss of market value, and furthermore, there is nothing in the decision to prohibit a court, if there is evidence of such losses, from awarding damages on the basis of the loss of royalty rule. Most important of all, it should be stressed that there is nothing in the decision to prohibit the awarding of substantial, as opposed to nominal damages, provided that there is evidence to establish such damages. ${ }^{128}$

In Prudential Trust Company v. Wagner Oils Limited, ${ }^{120} \mathrm{Mr}$. Justice McLaurin (who was now Chief Justice of the Trial Division) was again faced with the problem of assessing damages for breach of a covenant to drill a well. Chief Justice McLaurin interpreted the decision of the Supreme Court of Canada in the Cotter case as prohibiting him from awarding anything but nominal damages for breach of a covenant to drill a well. He stated as follows: ${ }^{130}$

If it were not for the Cotter decision, I would be disposed to fix the damages at some substantial amount, probably the cost of drilling a well. I still see nothing unfair in visiting a defaulting party with damages in this amount. The whole foundation of legitimate promotional efforts in the exploitation of oil are based on the assumption that the parties will not renege on such deals. However, the Cotter case has established that such damages must not be awarded, but it does hold that nominal damages are recoverable even though no nominal damages were fixed in that case.

It is respectfully submitted that, as stated above, there is nothing in the decision of the Supreme Court of Canada in the Cotter case prohibiting the awarding of substantial, as opposed to nominal damages, for breach of a covenant to drill a well. This was also the conclusion of Mr. Justice Riley in the Albrecht case.

In Albrecht v. Imperial Oil Limited, ${ }^{1: 11} \mathrm{Mr}$. Justice Riley in assessing damages for breach of a covenant to drill an offset well rejected the cost of drilling as the measure of damages. ${ }^{13:}$ Mr. Justice Riley awarded damages in the amount of royalties that the plaintiff would have re-

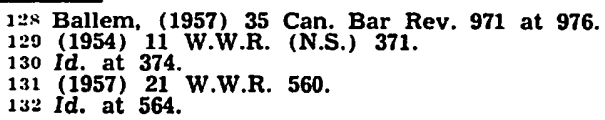


ceived on the gas that was drained away $(\$ 11.50),{ }^{133}$ and awarded damages for the loss in market value of the plaintiff's interest as a result of the defendant's failure to drill a well $(\$ 6,000),{ }^{134}$ a total of $\$ 6,011.50$.

Although it is not clear from the decision how the amount of loss of market value in the sum of $\$ 6,000$ was arrived at, it is submitted that this decision supports the proposition that in Canada damages for failure to drill a well will be calculated under the loss of royalty rule and under the loss in market value rule. It is further submitted that this decision supports the proposition that damages under both of these tests of damages for failure to drill a well, are damages within the ordinary course of things within the meaning of the first rule of Hadle v. Baxendale, and as such, are recoverable by the plaintiff without proof of special knowledge by the defendant of facts giving rise to the same, as Mr. Justice Riley did not inquire, whether or not at the time that the Offset Well clause was triggered, the defendant was aware of the plaintiff's intention to sell his retained interest.

Another Canadian decision on damages for breach of a covenant to drill a well is Madison Oils Limited v. Kleiman, an unreported decision of the Saskatchewan Court of Appeal. ${ }^{13.5}$ In that case, the plaintiff lessee sued for a declaration that its petroleum and natural gas lease was valid and subsisting, for damages caused by the defendant's interference with the plaintiff's efforts to drill an offset well and for damages caused by the defendant serving notice to lapse the plaintiff's caveat. The defendant counterclaimed for a declaration that the petroleum and natural gas lease was forfeited, and in the alternative, for damages for breach of contract consisting of payment of the royalties which he would have received had the offset well been drilled and for damages for loss of royalties on oil drained away from his land.

The petroleum and natural gas lease contained an Offset Well clause (almost identical in its wording with the Offset Well clause in the Albrecht case ${ }^{131}$ ) which was triggered by the placing on production of a "robber" well on May 16, 1961. On January 13, 1964, the defendant's solicitor, pursuant to the Notice of Default clause in the lease, served notice on the plaintiff that it must comply with the offset drilling commitment within 90 days. The plaintiff applied to the Department of Mineral Resources for a drilling licence to drill the offset well, but was unable to obtain the same because the defendant had advised the Department of his position that the lease had terminated by forfeiture. On April 10, 1964, within the 90 day Notice of Default period, the plaintiff commenced an action for the above described relief.

Mr. Justice Maguire held that the plaintiff was in breach of the Offset Well clause, but the said breach was governed by the Notice of Default clause, and the plaintiff being unable to remedy the default within the 90 day period because of the position taken by the defendant, the lease was valid and subsisting.

With respect to the defendant's claim for damages for loss of royalties that he would have received if the offset well had been drilled

133 Id.

134 Id. at $565-567$. 135 The judgment of the Court was delivered by $\mathrm{Mr}$. Justice Maguire on the 5 th day of

136 (1957) 21 W.W.R. (N.S.) 560. 
and for damages for loss of royalties by drainage, Mr. Justice Maguire stated as follows: ${ }^{13 i}$

The learned trial judge carefully reviewed all evidence before him and concluded that he was not reasonably satisfied that if a well had been drilled, it would be a producing well. This is a finding of fact and unless it can be shown that the trial judge has failed to consider relevant evidence, or has otherwise obviously erred, it is not for me to substitute my opinion or conclusion for his, even assuming that on all the evidence I might have arrived at a different conclusion.

As such, the defendant failed to establish damages caused by the plaintiff's breach of the covenant to drill an offset well on the basis of the "amount the offset well would have produced" formula. :i: Having arrived at this conclusion on the first claim for damages, it necessarily followed that any claim for loss by drainage had not been established, and the defendant did not recover any damages for the plaintiff's breach of an express covenant to drill an offset well.

Analyzing this decision in terms of the methods of assessing damages for breach of a covenant to drill a well discussed in this paper, it is respectfully submitted that the cost of drilling rule was rejected by implication, that there was no evidence of losses within the loss of royalty rule, that there was no evidence of loss of value within the loss of market value rule and that the value of information rule was inapplicable.

In the recent decision of Dolly Varden Mines Ltd. v. Sunshine Exploration Ltd., ${ }^{1: 3}$ the plaintiff was the owner of certain mining properties in British Columbia and entered into an agreement by which the defendant would examine, develop and bring the said properties into producttion and thereafter continue to operate the mines for the benefit of the parties according to their respective interests. The maximum term of the contract was to be 50 years, but depended on options to be exercised by the defendant and was subject to earlier termination in certain events.

In an action for damages for breach of the covenant to do the scheduled work, which included a programme of exploratory drilling, the plaintiff contended that it was entitled to the cost of the performance of the work, and alternatively, if the test to be applied was the difference in value of the property with the work performed and the work unperformed, then that difference in value is equivalent to the cost of doing the work. ${ }^{1+1}$ The trial judge held that the authority of Cunningham v. Insinger ${ }^{1+1}$ was not impaired by the Cotter case and granted the cost of doing the work as damages. ${ }^{1+2}$

On appeal, ${ }^{1+3}$ Chief Justice Davey rejected the defendant's submission that what the plaintiff had lost was the value of the chance that the work to be done by the defendant would produce a profitable mine in which the plaintiff would share. He concluded that what the plaintiff lost was not a chance that the mine would be successful but the work

137 Supra, n. 135 at 9-10.

13. 5 Williams and Meyers, Oil and Gas Law 153-156.

139 (1967) 64 D.L.R. 283.

1 to Id. at 308 .

$1+1$ (1924) 2 D.L.R. 433.

$1+2$ Supta, n. 135 at 315.

143 (1968) 69 D.L.R. 209. This decision was upheld by the Supreme Court of Canada, see (1969) 70 W.W.R. 419 . 
and resulting information that would show the worth of the property. Chief Justice Davey stated as follows: ${ }^{1+1}$

It seems quite clear that the direct and natural consequence of the appellant's default was to deprive the respondent of essential information about the value of its properties for which it had paid. The measure of that loss is the value of the information that respondent would have obtained from the performance by appellant of its contract to do the drilling. The value of that information cannot be determined by what it would have disclosed, for that is not known, but by what it would cost the respondent to obtain it, following the analogy of determining the value to the purchaser of goods bought but not delivered by the cost of replacing them.

Subsequent to the breach of the contract by the defendant, the plaintiff entered into an agreement with Newmount Mining Corporation of Canada Limited providing for the development of the mining properties. Commenting on the defendant's argument that the plaintiff had thereby mitigated its damages, Chief Justice Davey said as follows: ${ }^{14:}$

Before I leave this branch of the case, I must mention the argument of appellant that respondent suffered no loss because it now has an equally good contract with Newmount similar to the agreement with appellant, to explore and develop the properties. This subject was discussed by Viscount Haldane, L.C., in British Westinghouse Electric \& Mfg. Co., Ltd. v. Underground Electric Railways Co. of London, Ltd., [1912] A.C. 673 at 690-1. The subsequent transaction if it is to be taken into account, must be one arising out of the consequences of the breach and in the ordinary course of business. He distinguished Bradburn v. Great Western R. Co. (1874), L.R. 10 Ex. 1, on the ground that the contract there that gave the plaintiff his advantage was wholly independent of the relation between the plaintiff and defendant. In this case the respondent entered into the contract with Newmount, not because the appellant had failed to do the drilling, but because it had let its option lapse, as it had the right to do, and left the properties free for respondent to deal with. The contract with Newmount required that company to do certain exploratory work, in terms considerably different from schedule " $A$ ", but probably just as valuable to respondent. However, that was an incident in the new long range program for the exploration and development of the properties, and was not a substitute for the work and information appellant ought to have done and supplied.

The new arrangement with Newmount was res inter alios acta with which the appellant had nothing to do and which it was not entitled to set up. That is borne out by the fact that if appellant had done the drilling and supplied respondent with the reports that showed the mine to be valuable respondent would have been able to make a much better deal with Newmount because of the better prospects of success, and the saving of the expense for the exploration work already done by the appellant. On the other hand if the reports had been discouraging Newmount probably would not have been prepared to enter into the contract at all.

In summary, the Canadian decisions indicate that the cost of drilling rule will be the measure of damages for breach of a covenant to drill a well in a situation where the defendant driller has breached his contract to drill a well for the plaintiff; that in a situation where the plaintiff and the defendant both have an interest in the property on which the well is to be drilled, Canadian courts will grant damages for loss of royalty and for loss of market value; and that the Canadian courts will grant the cost of obtaining the information (which could be the cost of drilling the well) when the defendant has contracted with the plaintiff to provide him with certain information with respect to the drilling of the well.

\section{SPECIFIC PERFORMANCE}

It is generally said that specific performance of an obligation to drill a well will not be granted because of the court's reluctance to under-

144 Id. at 219.

145 Id. at 220. 
take the detailed supervision necessary to enforce a decree to drill an oil and gas well. ${ }^{14 i}$ It has however been suggested that the difficulties may be exaggerated, and in view of the difficulties in calculating the damages caused by the breach of a covenant to drill a well, specific performance should not be overlooked as a posible remedy. ${ }^{14 i}$ In $L a m p$ v. Locke, ${ }^{14 *}$ the Supreme Court of Appeals of West Virginia granted a mandatory injunction to compel the drilling of an offset well in a situation where the defendant lessee and others had conspired to drain the gas from under the plaintiff's land through a producing well on a neighboring tract five feet from the boundary line. The Court granted the injunction because no other remedy would prevent injustice. In Albrecht v. Imperial Oil Limited, ${ }^{1+9} \mathrm{Mr}$. Justice Riley refused specific performance stating, "in the light of the evidence adduced this is not a case for specific performance."

\section{J. LIQUIDATED DAMAGES}

A liquidated damages clause in the contract containing the covenant to drill a well will avoid both the theoretical and practical difficulties of assessing damages for breach of a covenant to drill a well and will avoid the expenses and delay of litigation. A liquidated damages clause is a clause in the contract whereby the parties agree on the amount that is to be paid as damages in the event of a breach of the contract. The parties to the contract realize that the amount of damages which will result from the breach of the contract is uncertain, and as such, want to avoid the difficulty of proving actual damages at the trial of the breach of contract. The courts implement the intention of the parties in the case of a liquidated damages clause by holding that upon breach of the contract the plaintiff is entitled to recover the stipulated sum without proof of the actual damage, and irrespective of the amount of the actual damage. ${ }^{1 ; 1}$

But a liquidated damages clause must be a genuine pre-estimate of the damages that would probably arise from a breach of the contract and a stipulated sum will be classed as a penalty where it is in the nature of a threat fixed in terrorem of the other party. ${ }^{1.2}$ If the courts treat the stipulated sum as a penalty, the plaintiff cannot recover the stipulated sum, but can recover only such damages as he can prove in the ordinary course of events.

Liquidated damages clauses for breach of an express drilling covenant have been upheld in California, Kansas, Kentucky, Oklahoma and Texas. ${ }^{1 .: 3}$ Williams and Meyers suggest the following as a form of liquidated damages clause, namely: ${ }^{154}$

In the event the well covenanted to be drilled as set out above is not drilled in accordance with the requirements of this agreement, the parties agree that the resulting damages to the lessor [or assignor] will be indefinite, uncertain and speculative, and they therefore agree that lessee [or assignee] will pay to lessor [or assignor] as liquidated damages the sum of $\$$.................... It is

1 11; Van Derhoof, (1956) 3 U.C.L.A. Law Rev. 586 at 587.

1.7 Huie, Walker and Woodward, Cases and Materials on Oil and Gas 518 (1960).

1i. (1921) 108 S.E. 899.

$1+$ !) (1957) 21 W.W.R. 560.

1.ic) Id. at 564 .

(i) See generally, Mayne and McGregor On Damages, 206-255 (12th ed.)

$1: 2$ See Dunloy Pneumatic Tyre Co. v. New Garage and Motor Co. 1915 A.C. 79 for the rules for distinguishing liquidated damages from penalties.

1.: 5 Williams and Meyers, Oil and Gas Law Para. 885.5. p.611.

1 it Id. at 610 . 
further agreed that lessor [or assignor] need not establish that any actual damage occurred upon breach of the covenant, it being the intention of the parties to establish hereby the damage that can be forseen from the breach of the covenant at this, the time of the making of such agreement.

Instead of agreeing that one party shall, upon his breach of the contract pay to the other a stipulated sum as liquidated damages, another method that can be used to avoid the difficulties of assessing damages is the deposit of such a sum with the promissee at the time of the contract, with the provision that upon the depositor's breach of the contract, the sum deposited shall be forfeited to the promissee. The first issue that must be resolved in a situation where a party to a contract has paid over money to the other party is whether or not the parties had or had not provided that such money should not be recoverable upon the payer's default. ${ }^{15 i}$ If there is no agreement, whether express or implied, that money paid shall not be returnable on default, then nothing in the nature of liquidated damages exists in the contract, and the plaintiff can only retain such portion of the sum deposited, as he can prove in the ordinary way, and the balance must be returned to the depositor. ${ }^{150}$

If, on the other hand, there is an agreement that the deposit shall not be returnable, then, whether or not the money deposited is or is not a penalty as opposed to liquidated damages paid before the breach, the plaintiff will be unable to recover the same at common law. Equity however has a general right to relieve against penalties, not only by refusing to enforce the same, but also by giving affirmative relief to the victim by ordering recovery of money already paid by him. ${ }^{15 i}$

Another method that is used to secure performance of a covenant to drill a well is to require the defendant to provide the plaintiff with a performance bond. The condition of a performance bond is that the promissor will truly and faithfully perform the particular contract in respect of which the bond has been issued in accordance with all the terms and conditions thereof. Accordingly, any failure to perform, or any other breach of the contract, will entitle the owner to call on the bonding company for indemnification for any loss suffered as the result of such failure or breach. A performance bond may give the bonding company the option to complete the contract or to pay damages for breach thereof. If the bonding company elects to pay damages for breach of the covenant to drill a well, the plaintiff is in exactly the same position as he was in without the performance bond, in that he must establish his actual damages; if however, the bonding company is required to complete the contract, then the plaintiff will have his covenant to drill a well performed.

1.:5 See 1 Lewis and Thompson, Canadian Oil and Gas. Div. C. Form B.2lal. Clause 2. for an example of a Farmout Agreement requiring a deposit or a performance bond. :1 Mayne and McGregor, supra, n. 151 at 236-238. 157 Id. at 238-239. 